أهمية القروض الزراعية في تبني زراع الخضر الصيفية للتقانات الزراعية الحديثة في قضاء الثرقاط بمحافظة صلاح الاين وعلاقتها ببعض المتغيرات

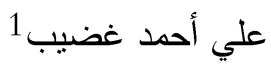

الززراعية تسهم وبثكل واضح في تقليـل التيــاليف بالنســبة للزراع مما تزيد من صافي الربح) احتلت المرتبة الأولى ويوزن

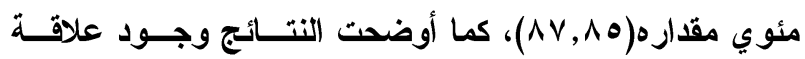

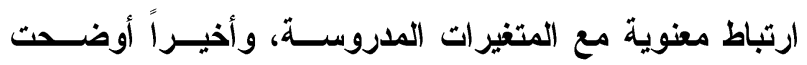

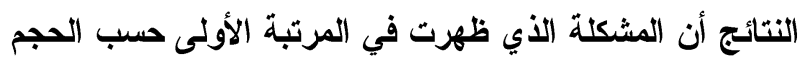

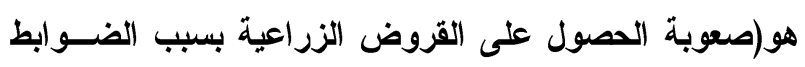

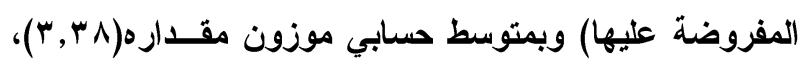

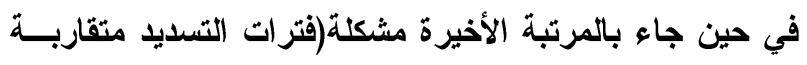

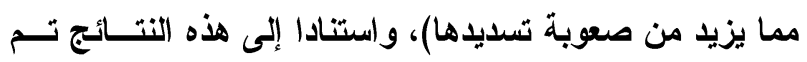
التوصل إلى عدد من الاستتناجات واقتراح بعض التول التوصيات.

\section{المقدمة و المشكلة البحثيــة}

يو اجه العالم اليوم تحدياً كبير ا يقف بوجـه طموحاتــه

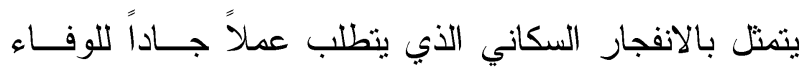

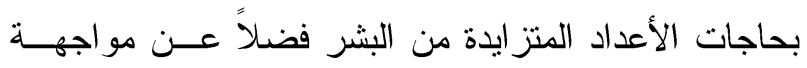

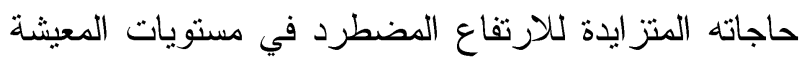

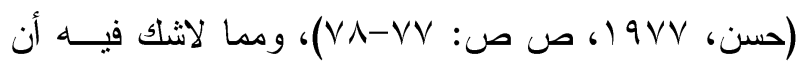
الثورة المعرفية و التكنولوجية التي يعيشها المجتمع المعاصر

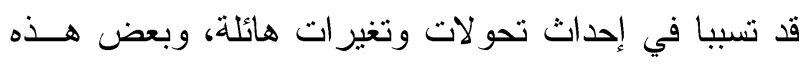
التحولات و التغيرات تتسم بالإيجابية وبعضها الاخر يتســ بالسلبية، ولمواجهة منطلبات نلك التحو لات و التغيرات كان

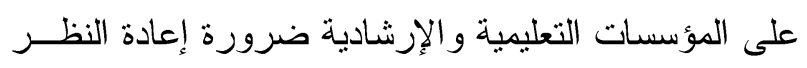

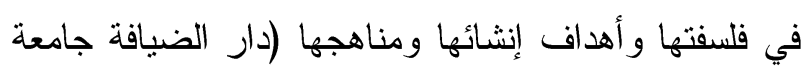

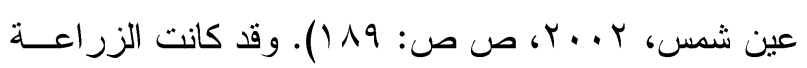

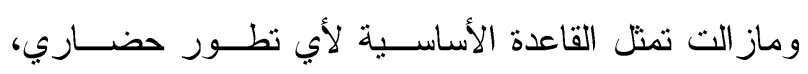

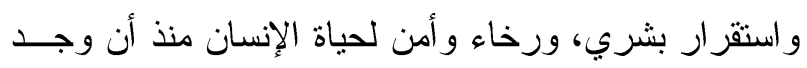

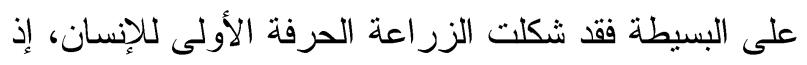

الملخص العربى

يهيف هذا البحث إلى التعرف على أهمية القروض الزراعية

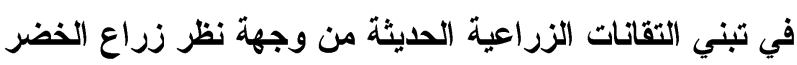

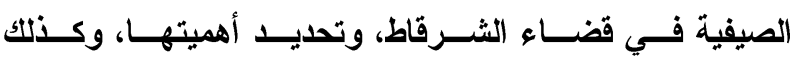

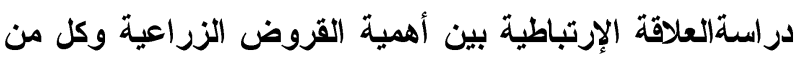

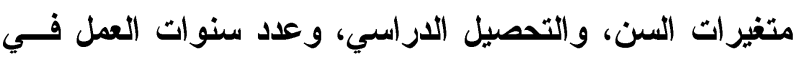

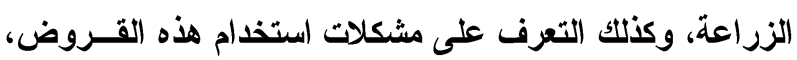

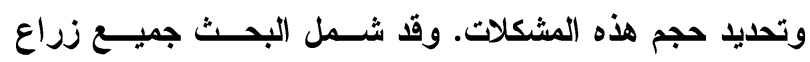

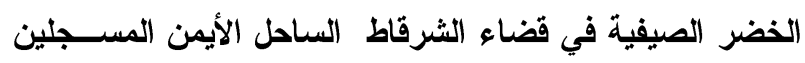

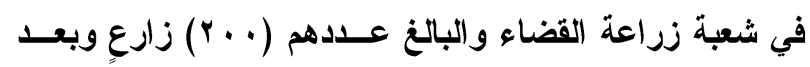

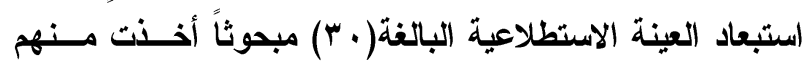

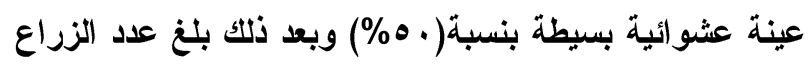

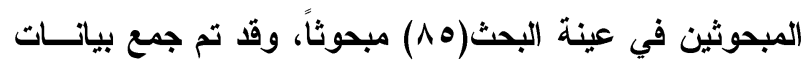

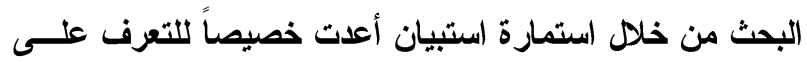

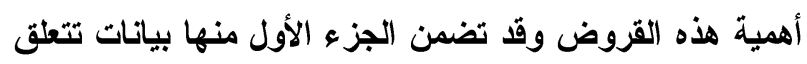

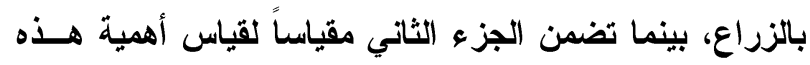

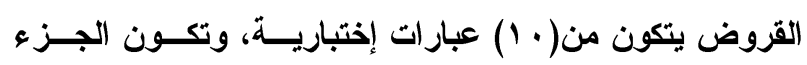

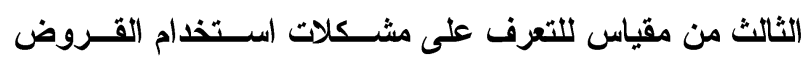

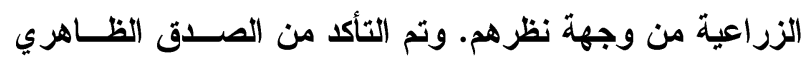
وصدق المحتوى، كما تم حساب الثبات بطريقة التجزئة النصفية

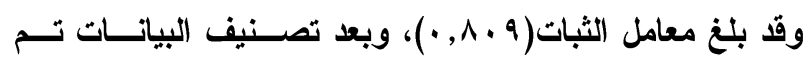

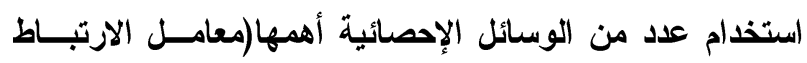

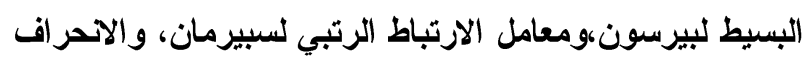

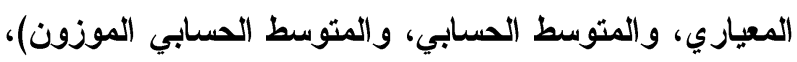

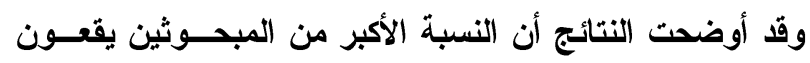

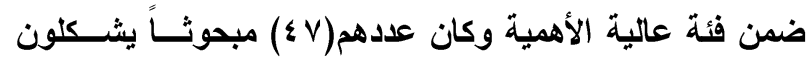

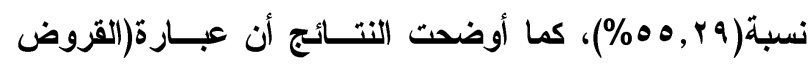

' كلية الزراعة -جامعة تكريت- قسم الاقتصاد والإرشاد الزراعي

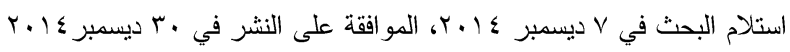


كلا المجالين المادي و المعرفي، المادي المتعلق بــالقروض الزر اعية، والمعرفي المتعلق بالمعلوماتالإرشادية الزر اعية، فقد وجد(غضيب) في در اســته لمعوقــات نقــل التقانــات الزر اعية في محافظة صلاح الدين وجود ضعف وقصــور و اضـح في دور الإرشاد الزر اعي كما توصل إلــى وجــود

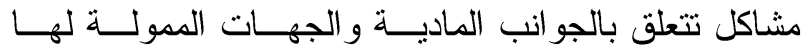

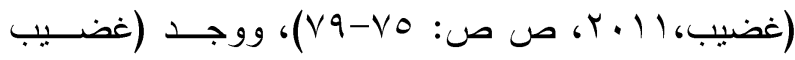
وطلال) في دراسة الأنشطة الإرشادية للموظفين الزر اعيين

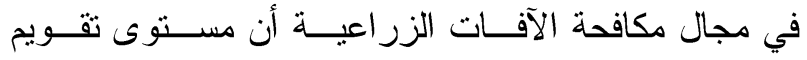
الأنشطة الإرشادية الزر اعية في محافظـــة صــلاح الــدين

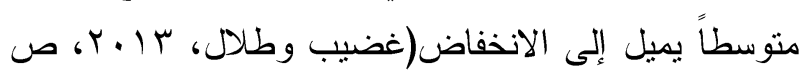

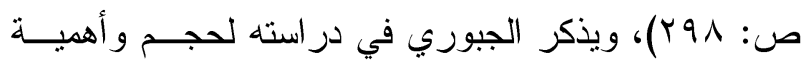
مشاكل نقل التقانات الزر اعية في محافظة نينوى أن هنــاك مشاكل عدة تتعلق بالجو انب المعرفية المتعلقــة بالإرشـــاد الزر اعي، وكــذلك مشــاكل تتعلـق بالجو انــب الماديــة

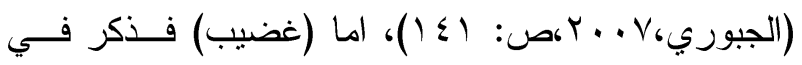
در استه عن دور المرشدين الزراعيين في نقــلـ التقانــات الزر اعية للزر اع في محافظة نينوى بأن من أهم مشاكل نقل التقانات الزر اعية مشكلة قلة التخصيصات المالية في مجال نقل التقانات الزر اعية اذ جاءت بالمرتبة الثانية مــن بـين

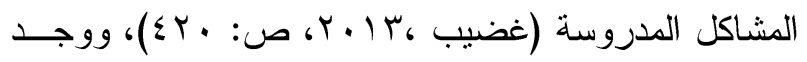
(غضيب) في دراسته لدور المر اكز البحثيــة فــي تكيبــف

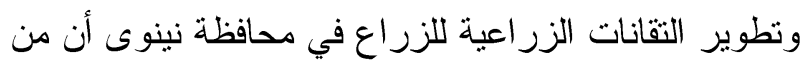
بين مشاكل تكييف وتطوير التقانات الزر اعية مشكلة قلـــة التخصيصات المالية للبحوث الزر اعية، (غضــيب، I ا . Y، ص: صYVT) كذللك وجد غضيب في در استه لــدور شــركة التجهيزات الزر اعية في توفير وتوزيع التقانات الزر اعيــة

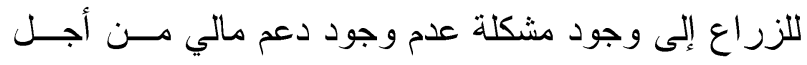

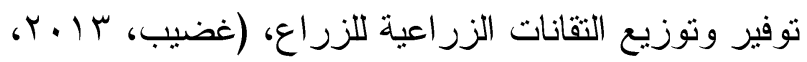
ص: 1 • ع)، كما وجد(غضــيب ومحمــود وســمير) فـي در استهم عن أهمية القروض الزر اعية لزر اع الحنطة فـي محافظة صلاح الدين أن القروض الزر اعية تساعد الزراع
حصل منها على غذائه وكسائه ومأو اه، وبها حــافظ علــــ

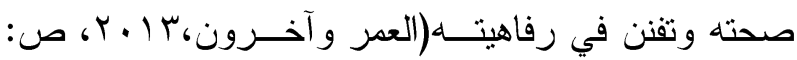
(1)

ويعد القطاع الزراعي من الأنشطة الاقتصادية المهــــة

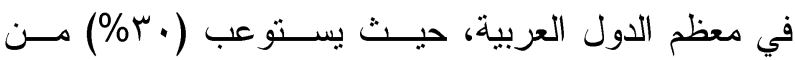
إجمالي القوى العاملة، مما جعله مصدر اً رئيسـياً لمعيشـــة نسبة كبيــرة مــن الســكان (المنظمـــة العربيــة للتتميــة

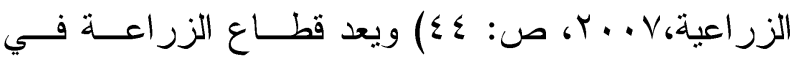
العراق من أكثر القطاعات مساهمة في الاقتصاد العراقـي، بل يعده البعض القطاع الأول بالنظر لدوره كقاعدة يـــوفر الغذاء للسكان، ويستوعب عدد من الأيدي العاملة، فضـــلاً

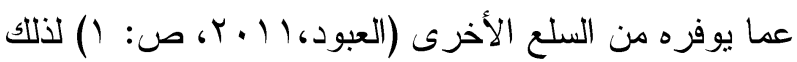
يقتضي تحديث قطاع الزر اعة في أي دولة نامية ضــرورة

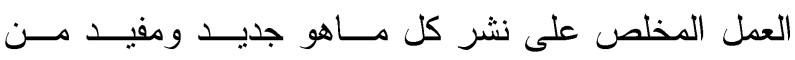
تكنولوجيات مزرعية ومنزلية ذات الصبغة التطبيقية بــين الزراع وأسرهم، ومحاولة إقناعهم بها، وحثهم على وضعها موضـع التطبيق الفعلي واستمرار تبنــيهم لهــا، (الطنــوبي

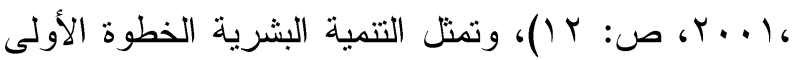
و الأساسية في عملية التتمية الثاملة فــي مختلـــ الــدول المتقدمة و النامية على السواء، حيث يعد العنصر البثــري القادر على استيعاب المستجدات الحديثة وتطبيقها بدرجــة عالية من المهارة و الكفاءة هو في واقع الأمر العنصر الذي يتوقف عليه إدخال وتطوير التقنيات الحديثــة، (المنظمــة

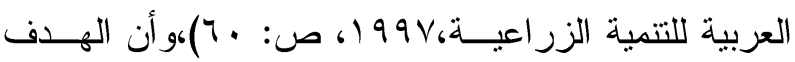
الرئيسي للإرشاد الزراعي في العالم تحسين وزيادة الإنتاج الزر اعي عن طريق تحديث أســاليب الزر اعــة و إدخــال التقانات التي إبتكرها العلم من التقاوي المحسنة، والأسمدة، و المركبات الكيميائية المختلفة، والالات الزراعية المختلفة،

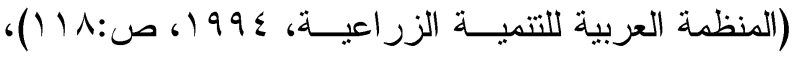
وأن تحسين وزيادة الإنتاج الزراعي تتأتى من خلال الدعم المالي، بالإضافة إلى المعرفي، وقد اثنارتالدر اسات المختلفة في مجال نقل التقانات الزر اعية إلى وجود حاجة ماسة وفي 


$$
\text { علي أحمد غضيب: أهمية القروض الزر اعية في تبني زراع الخضر الصيفية للتقانات الزر اعية الحديثة ... }
$$

r- تحديد أهمية القروض الزر اعية في تبني زراع الخضر الصيفية التقانات الزر اعية الحديثة.

بـ در اسة العلاقاتالإرتباطية بين درجة اهميــة القـروض

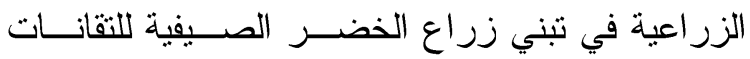
الزر اعية الحديثةوبينخصائص المبحوثين المتمثلة فــي

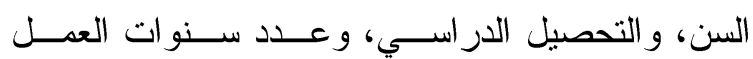

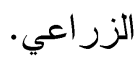

ع - التعرف على مشكلاتالحصول على القروض الزر اعيــة من قبل زراع الخضر الصيفية.

\section{المتغير ات البحثية}

تمثلت المتغيرات البحثية في نوعين من المتغيرات:

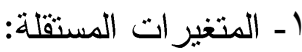
تمثلت المتغير ات المستقلة في:

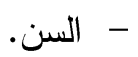
- - - التحصيل الدراسي. - - عدد سنو ات العمل الزر اعي.

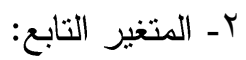

تمنل المتغير التابع في اهمية القروض الزراعية في تبني زراع الخضر الصيفية للتقانات الزر اعية الحديثة.

\section{الفرضيات البحثية}

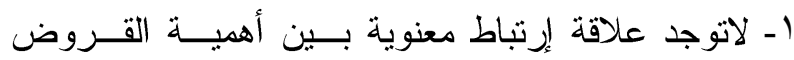
الزر اعية في تبني زراع الخضــر الصـــفية للتقانــات

$$
\text { الزر اعية الحديثة و السن. }
$$

r- لاتوجد علاقة إرتباط معنوية بــين أهميــة القـروض

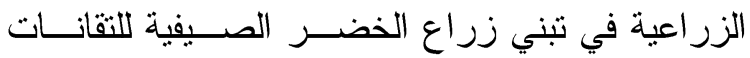

$$
\text { الزر اعية الحديثة و التحصيل الدر اسي. لئ. }
$$

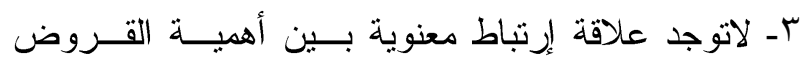

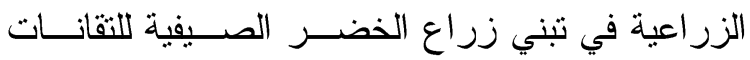
الزر اعية الحديثة و عدد سنوات العمل في الزر اعة.
على تبني التقانات الزر اعية الحديثة وقد احتلــت المرتبــة الأولى من بين العبارات المدروسة (غضــيب و آخـرون،

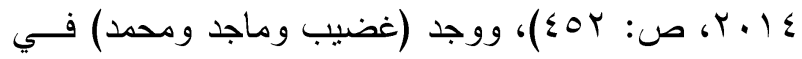

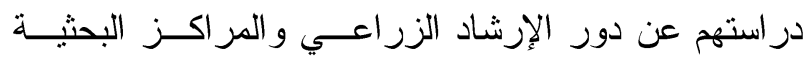
و الخدمات الزر اعية في نقل وتطـــــير وتــوفير التقانــات الزر اعية أن هنالك حاجة ملحة جداً للقروض الزر اعية وذلك لاستخدامها في شراء التقانات الزر اعية الحديثة لممارســة فئه

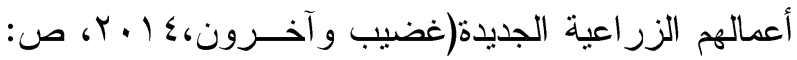
(آ§)، وبما أن زراع الخضر هم أكثر استخداما للتقانات الزر اعية من غيرهم من الزراع في منطقة البحـــث لــذلك

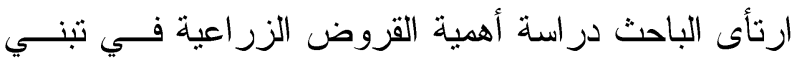

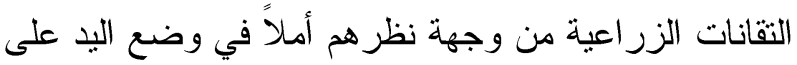

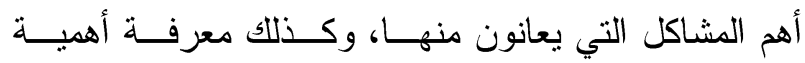
القروض، و انعكاسات استخدامها في مجال تبنــي التقانــات الزر اعية، ولعدم وجود در اسات سابقة حول موضوع ع أهمية التقانات الزر اعية في تبني التقانات الزر اعية جاءت فكــرة البحث للإجابة عن التساؤلات التالية: - ما أهمية القروض الزر اعية في تبني التقانات الزراعية الحديثة من وجهة نظر زراع الخضر الصيفية في قضاء الثرقاط بمحافظة صلاح الدين؟

- ما العلاقة الإزتباطية بــين درجـــة أهميــة القــروض الزر اعية في تبني التقانات الزر اعية الحديثة من وجهــة نظر زراع الخضر الصيفية في قضاء الثرقاط بمحافظة صلاح الدينوبعض خصائص الزر اع؟ - ما مشكلات استخدام القروض الزراعيــة فـــي تبنــي التقانات الزر اعية الحديثة من وجهة نظر زراع الخضر الصيفية في قضاء الثرقاط بمحافظة صدلح الدين؟. أهداف البحث ا - التعرف على أهمية القروض الزر اعية في تبنـي زراع الخضر الصيفية التقانات الزر اعية الحديثة. 
ولغرض جمع البيانات من المبحوثين تم إعداد اســتمارة إستنيان تتألف من ثلاثة أجزاء:

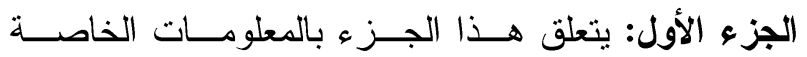
بالخصائص الثخصية للمبحوثين وهي (السن، و التحصـيل الدر اسي، و عدد سنو ات العمل في الزر اعة). الجزء الثـــي: تضمن هذا الجزء عدداً من العبارات(عشرة

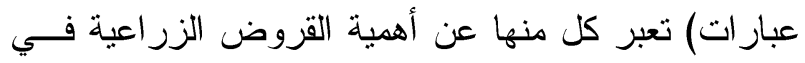
تبني زراع الخضر الصيفية للتنانات الزر اعية الحديثة، وقد

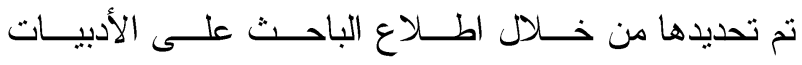
و المصادر وتحكيم المتخصصين الإرشــاديين فــي كليــة الزر اعة بجامعة تكريت.

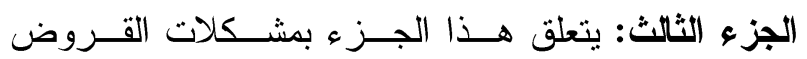

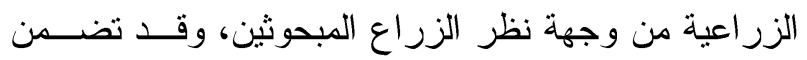

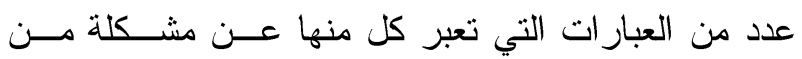

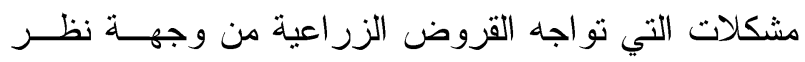

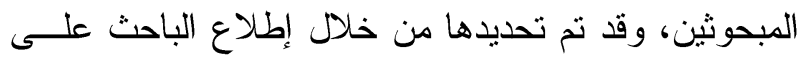

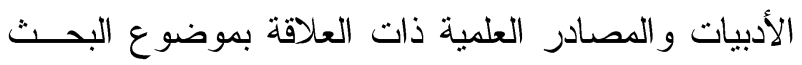

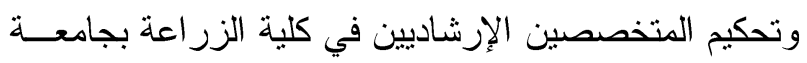

$$
\text { تكريت }
$$

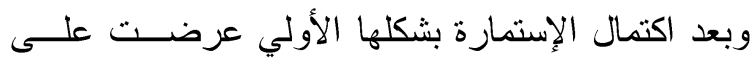
متخصصين في الإرشاد الزر اعي في كلية الزراعة جامعة

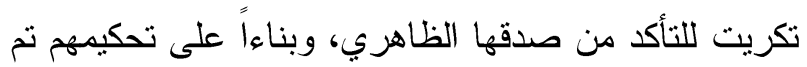
حذف وتعديل وصياغة بعض العبـار ات لتصـبح ملائـــة

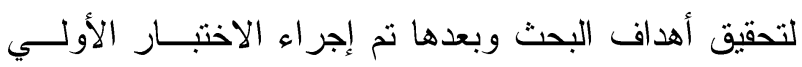

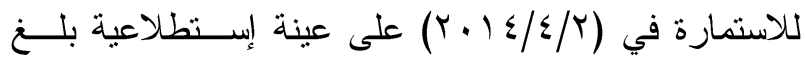

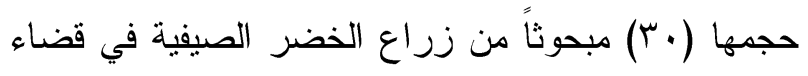

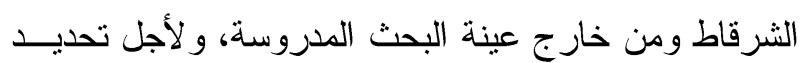

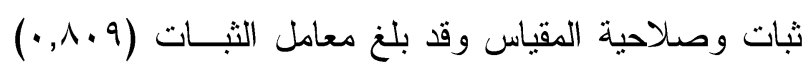
ومعامل الصلاحية (199,، •) و الذي يدل على الثبات العالي للمقياس ولعباراته و التي يمكن اعتمادها بالقياس، وأن قـيميم الثبات و الصلاحية مقبولة حيث يعد الثبات مقبو لاً إذا وصلت ولته
التعاريف الإجرائية

ا - القروض الزراعية: جميع ألأمو ال التي يحصل عليهــا

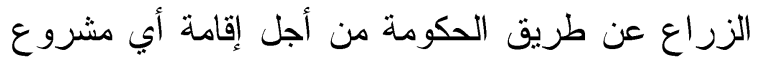
زر اعي ويتم تسديدها حسب الضو ابط المعمول بها.

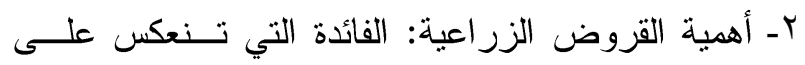
الزراع من جر اء استخدام القروض الزر اعية.

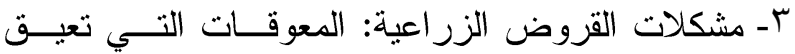

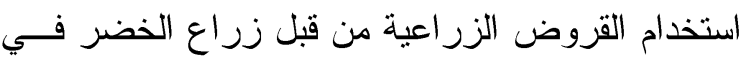
قضاء الشرقاط.

ع- زراع الخضر الصيفية :- جميع زراع الخضر الصيفية

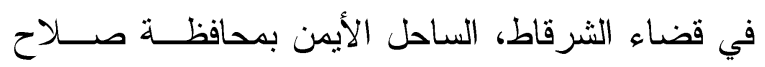
الدين المسجلين في شعبة زر اعة قضاء الثرقاط.

\section{طريقة إجراء البحث}

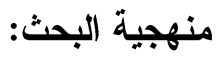

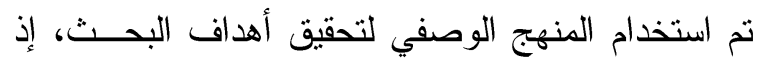
يعد هذا المنهج مناسباً للوصول إلى بيانات وحقائق تفصيلية

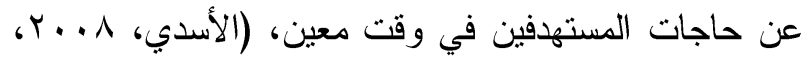

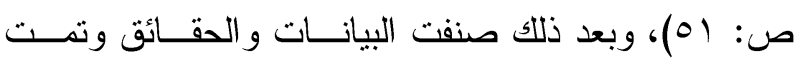
معالجتها وتحليلها تحليلا دقيقا وتبيين الاقتران لاســتخلاص ولتص

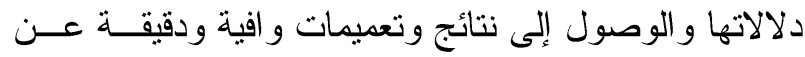

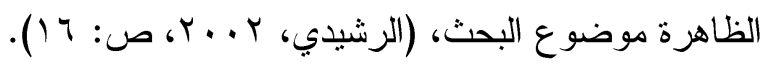

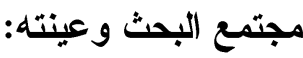

تمثل شاملة البحث زراع الخضر الصيفية المسجلين في

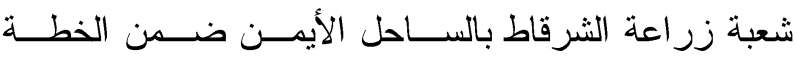

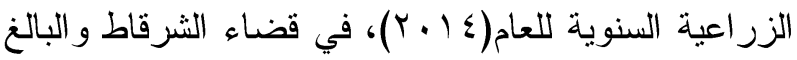
عددهم( ·r) زارع، وقد استبعاد العينة الاستطلاعية البالغة

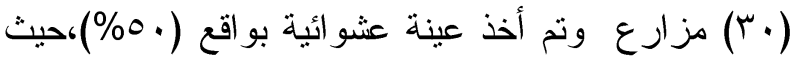

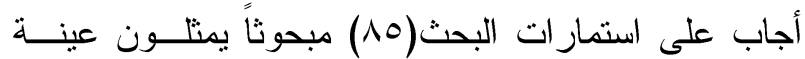
البحث. 
r- عدد سنوات العمل في الزر اعي: نم قياسها بعدد سنوات العمل الزر اعي و اعطيت درجة واحدة لكل سنة.

قياس مشكلات استخدام القروض الزر اعية: لغرض تحليل البيانــات المتعلقــة مشــكلات اســتــدام

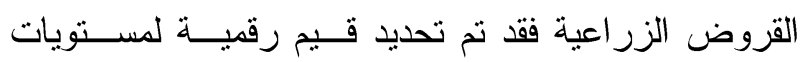

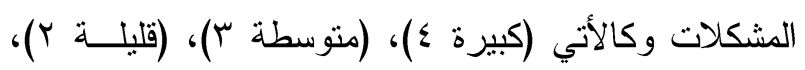

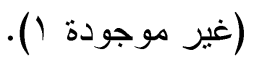

\section{النتائج ومناقشتها}

نعرض فيما يلي النتائج التي تم التعرض لها و التي

$$
\text { تمنلت فيما يلي: }
$$

أولاً: التعرف على أهمية القروض الزراعية في تبني زراع الخضر الصيفية للتقانات الزراعية الحديثة.

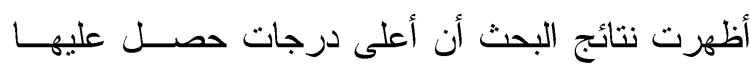
المبحوثين من استجابتهم على اهميةالعبار ات العشر لنوعية أهمية القروض الزر اعية (rV)، وأدنى درجة هـي (·) (1)

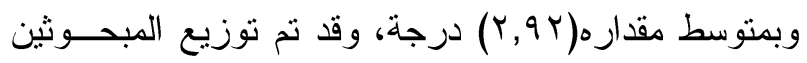
على ثلاثة فئات للأهمية وذلك بالاستتاد إلى المدى الفعلــي،

$$
\text { وكما موضح في الجدول (1). }
$$

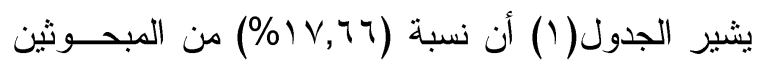
يقعون ضمن فئة قليلة الأهمية، وبمتوســط مقــداره (1, (1)

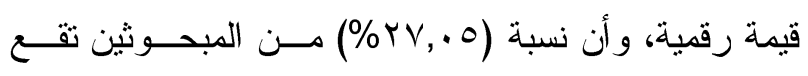

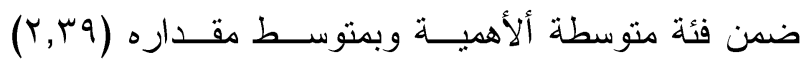
درجة، وأن نسبة (90,\%) من المبحوثين تقع ضمن فئة وهن عالية الأهمية وبمتوسط مقداره (ب,00) قيمة رقمية،

\begin{tabular}{|c|c|c|c|}
\hline متوسط درجات الأهمية & النسبة المئوية & العدد & الفئات (درجة) \\
\hline $1, \wedge$ & 18,74 & 10 & ( ( ) قليلة الأهمية \\
\hline$r, r q$ & $r V, .0$ & r & ( ) متوسطة الأهمية \\
\hline$r, 00$ & 00,19 & $\varepsilon V$ & (rV-rq) عالية الأهمية \\
\hline & $1 \ldots$ & 10 & المجموع \\
\hline
\end{tabular}

جدول ا ـ توزيع المبحوثين وفقاً لأهمية القروض الزراعية في تبني زراع الخضر الصيفية للتقانات الزراعية
قيمته إلى أكثر من (•V, •))، و أكثر إرضاءً كلما أقترب من

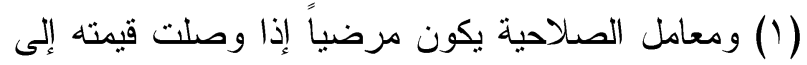

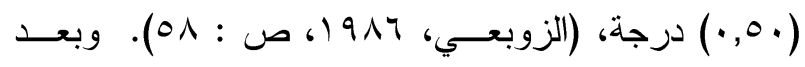

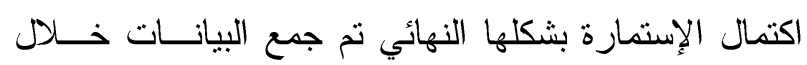

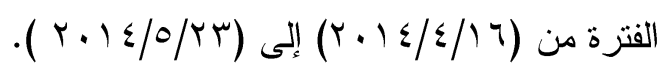
بناء المقياس

قياس أهمية القروض الزراعية: بعد تحديد عبار ات أهمية القروض الزر اعية بصــورتها

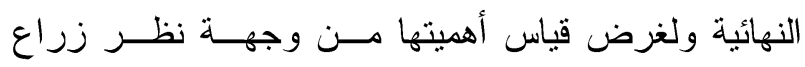
الخضر الصيفية في قضاء الثرقاط تم اســتخدام مقيــاس رباعي مكون من أربعة مستويات هي( كبيرة، متوســة فئ،

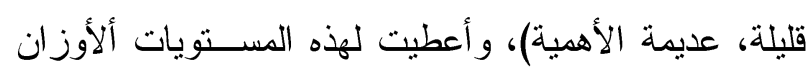

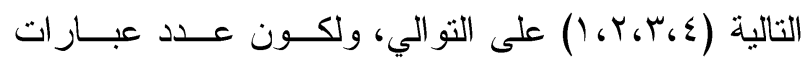

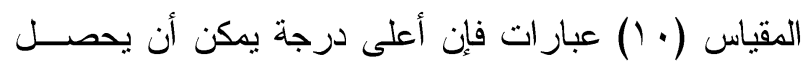

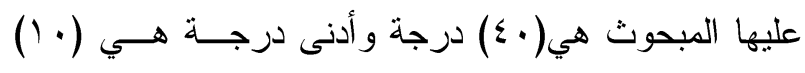
درجة.

\section{قياس العوامل المستقلة:}

1 - السن: تم قياسه بعدد سنوات سن المبحوث وقت جمـع البيانات.

r- التحصيل الدراسي: تم قياسة وفق المســتويات التاليــة (امي، خريج ابتدائية، خريج منوسطة، خريج اعداديــة،

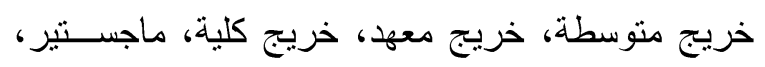

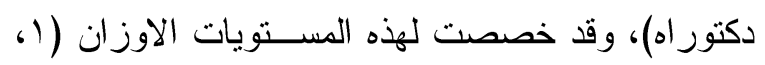

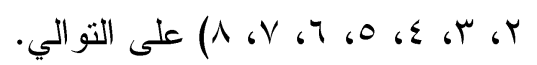




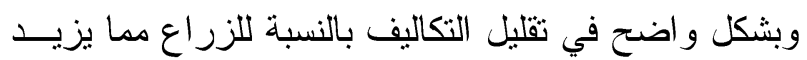

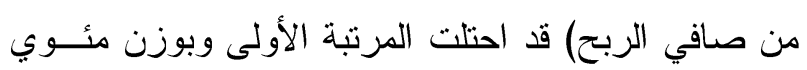

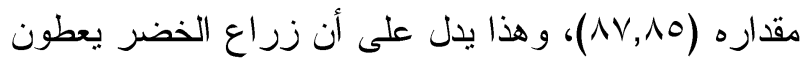
لهذه الفقزة أهمية كبيرة من بين عبار ات البحث، أما الفقــرة

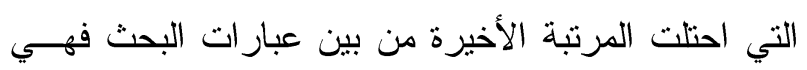
فقرة ( القروض الزراعية تمكن الزراع من اقتتاء النقانــات

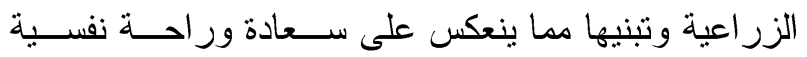

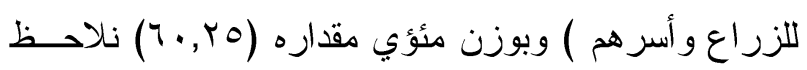

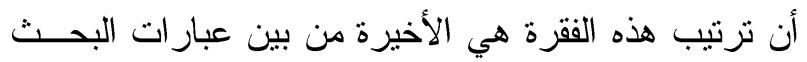

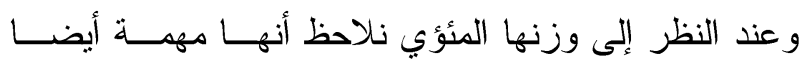

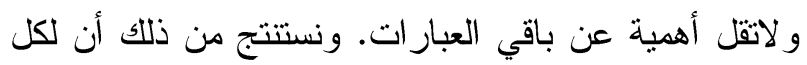

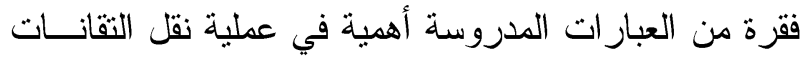

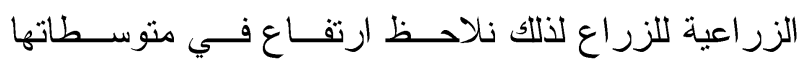

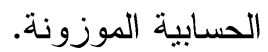

ويتضح من ذلك أن غالبية المبحوثين يقعون ضـــن فئسة

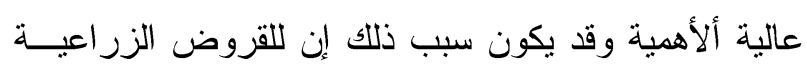

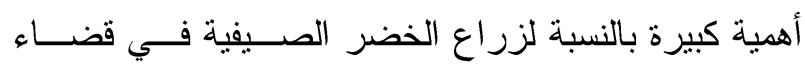

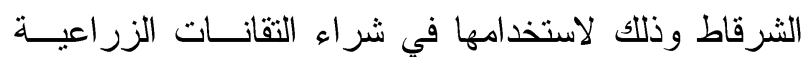

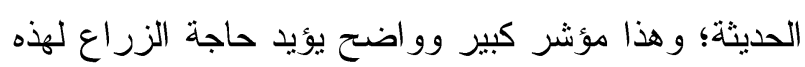

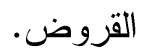

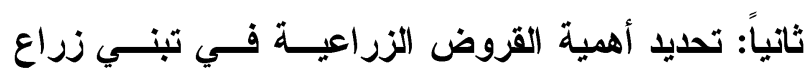
الخضر الصيفية التقانات الزراعية الحايثة.

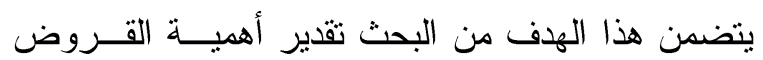

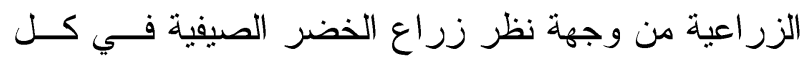

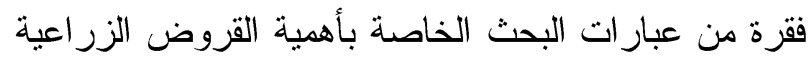

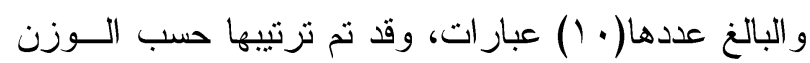
المئوي الذي حصلت عليه العبارات بعد تحديد متوسط كـلــل

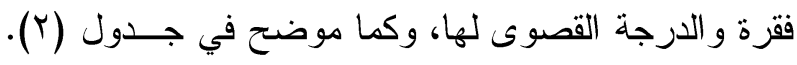

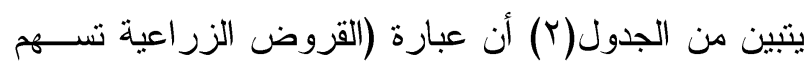

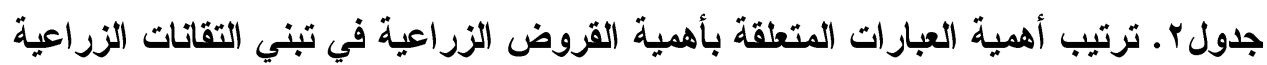

\begin{tabular}{|c|c|c|c|c|}
\hline ترتب المئوي الفقرة & للمقئوية & متوسة & العبارات & $ت$ \\
\hline 1 & $\Lambda V, \wedge O$ & $r, 01$ & يزيد من صافى الزربح. تسهم وبشكل واضح في تقليل التكاليف بالنسبة للزراع مما & 1 \\
\hline r & $14, r_{0}$ & $r, \leqslant 0$ & 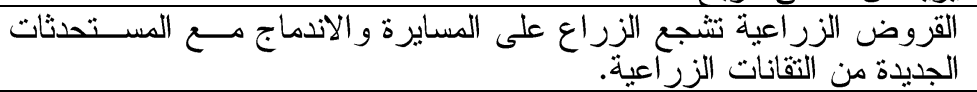 & r \\
\hline$r, 0$ & $10, r_{0}$ & $r, \xi 1$ & القروضثة. الزراعية تزيد من حرص الزراع على الأخذ بالتوصـبات العلميــة & r \\
\hline$r, 0$ & $10, r_{0}$ & $r, \varepsilon 1$ & القروض الزر اعية تنع من استغلال المر ابين للزر اع. & $\varepsilon$ \\
\hline 0 & $A Y, Y O$ & $r, r q$ & القروض الزر اعبة تقلل من البطالة بين صفوف الزرراع & 0 \\
\hline 1 & v৭, ২० & $r, 11$ & لها. القروض الزر اعية تمكن الزراع من تبني الثقانات الزراعية حسب احتباجاتهم & 7 \\
\hline $\mathrm{v}$ & $V Y, Y_{O}$ & $r, .9$ & القروض الزر اعية لها دور حقيقى فى إمكانية زيادة الإنتاج. & $\mathrm{v}$ \\
\hline$\Lambda, 0$ & 79 & $r, T \varepsilon$ & القتهلاكها. الزراعية تؤدي إلى تعزيز استخدام نوعية التقانات الزراعية بدلا من & $\Lambda$ \\
\hline$\Lambda, 0$ & 74 & $r, T \varepsilon$ & 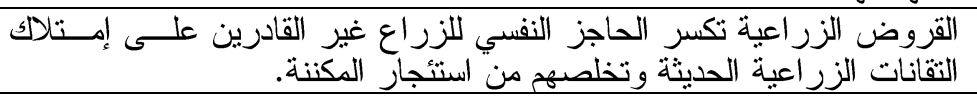 & 9 \\
\hline 1. & $7 .$, ro $^{2}$ & $r, \xi 1$ & 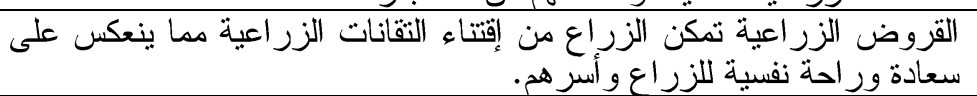 & 1. \\
\hline
\end{tabular}


r- التحصيل الدراسي:

أظهرت نتائج البحث أن المبحوثين موزعين على ثمانية

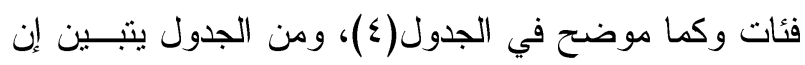

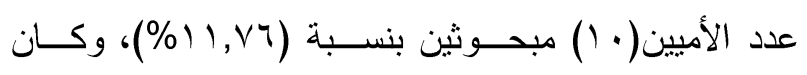

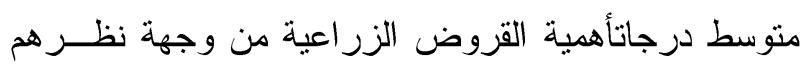

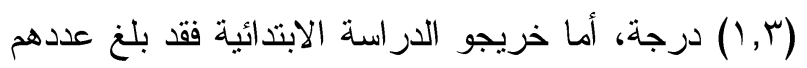

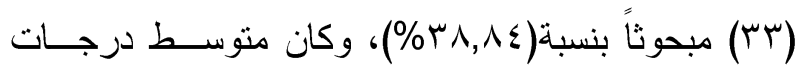

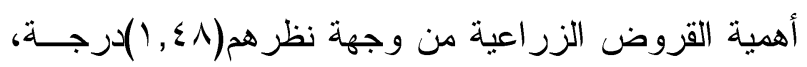
أما خريجو الدراسة المنوسطة فقد بلغ عددهم (V) (IV) مبحوثاً

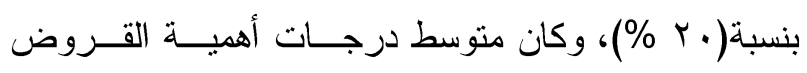

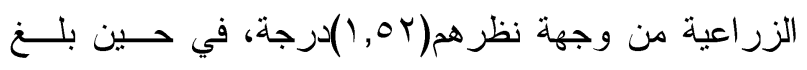

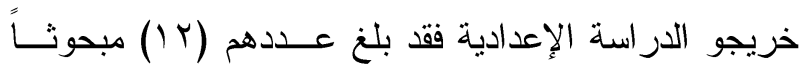

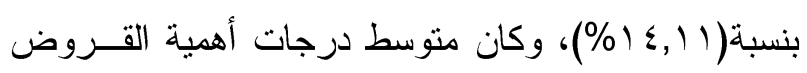

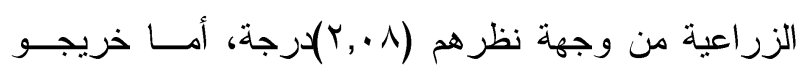

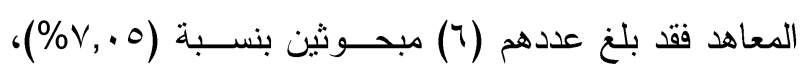

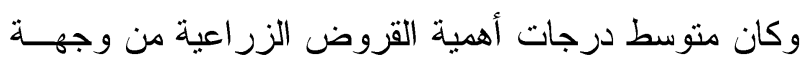

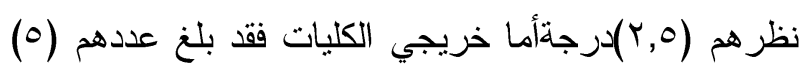

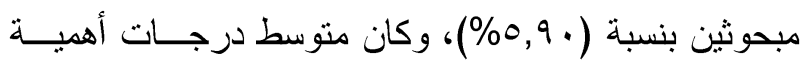

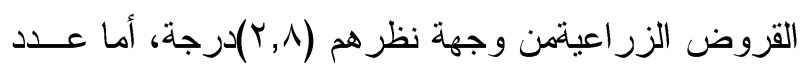

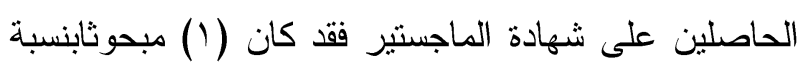

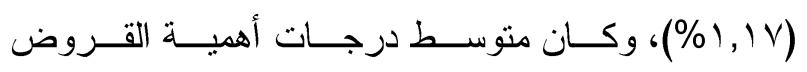

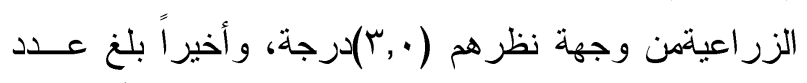

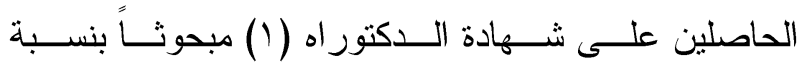

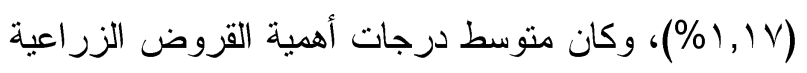
من وجهة نظره (•,r)، وكما موضح في الجدول (ع).

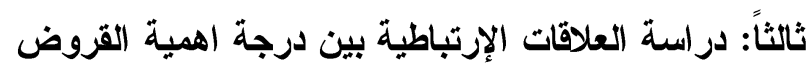

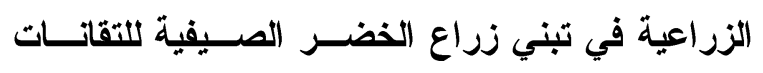

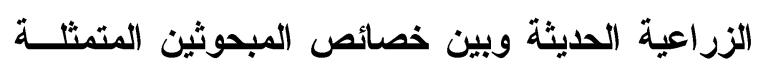
في السن، و التحصيل الاراسي، وعدد ســنوات العـــل

الزر اعي. 1- السن:

أظهرت نتائج البحث أن أعلى سن للمبحوثين (1/) ســـنة،

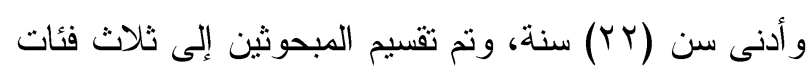

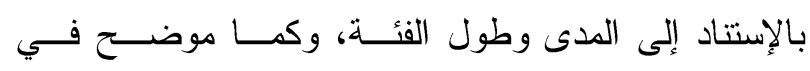
جدول(r).

يوضح الجدول(r) أن الفئة الأولى كان عـددهم (1) (1)

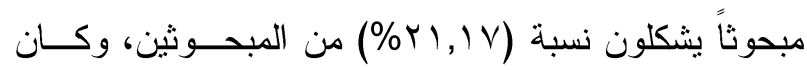

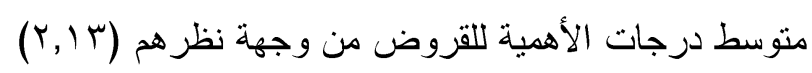

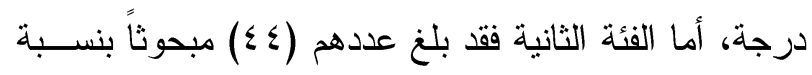

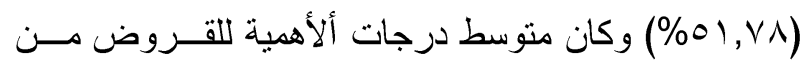

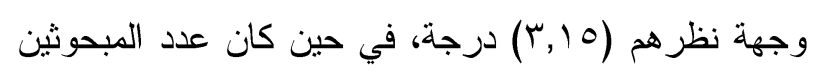

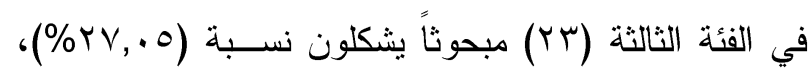

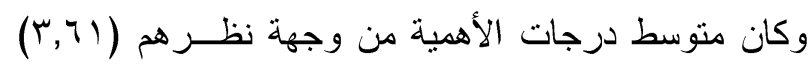

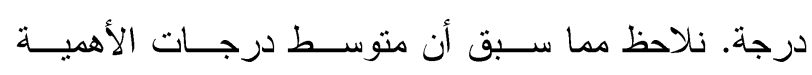

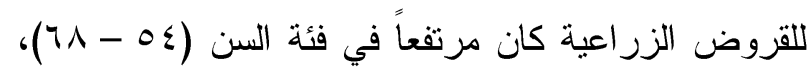

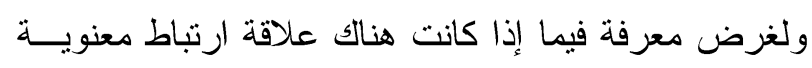

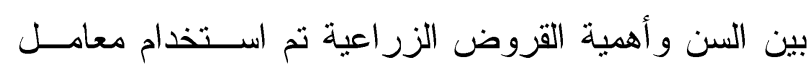

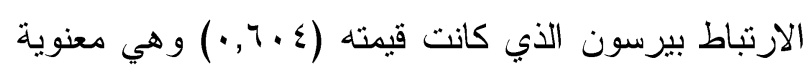

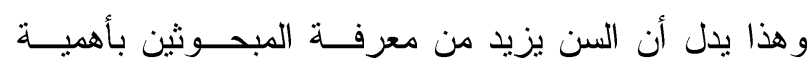

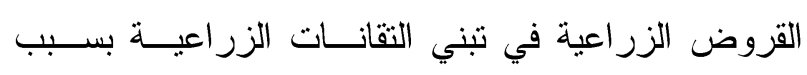
خبرتهم وزيادة وعيهم من خلال تجارب العمر الطويلة.

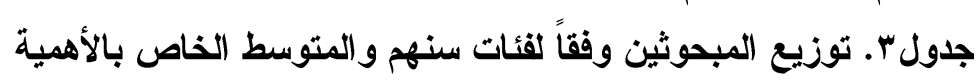

\begin{tabular}{|c|c|c|c|c|c|}
\hline معامل الارتباط (بيرسون) & متوسط درجات لأهمية & النسبة المئوية & العدد & الفئات (سنه) & 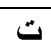 \\
\hline \multirow{4}{*}{$\cdot, 7 \cdot \varepsilon$} & r,IT & $r, I V$ & 11 & ) & 1 \\
\hline & $r, 10$ & $01, Y \wedge$ & $\varepsilon \varepsilon$ & (or - r ) سن متوسط & $r$ \\
\hline & $r, 7)$ & $T V, .0$ & Tr & 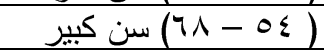 & $r$ \\
\hline & & $1 \ldots$ & 10 & 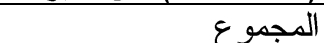 & \\
\hline
\end{tabular}




\begin{tabular}{|c|c|c|c|c|c|}
\hline معامل ألارتباط بيرسون & متوسط درجات الأهمية & $\%$ & العدد & الفئات & ت \\
\hline \multirow{9}{*}{ •, 199} & $1, r$ & $11, \times 7$ & 1. & أمسى & 1 \\
\hline & $1, \leqslant \wedge$ & 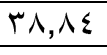 & r & خريج ابتدائية & $r$ \\
\hline & $1,0 Y$ & $r \cdot, \cdots$ & $1 V$ & خريج متوسطة & $r$ \\
\hline & $r, \cdot \Lambda$ & $1 \varepsilon, 11$ & $1 r$ & خريج إعدادية & $\varepsilon$ \\
\hline & $r, 0$ & $V, .0$ & 7 & خريج معهد & 0 \\
\hline & $r, \Lambda$ & 0,9 . & 0 & خريج كلية & 7 \\
\hline & $r, \cdot$ & $1,1 \mathrm{~V}$ & 1 & ماجستير & $V$ \\
\hline & $r, \cdot$ & $1,1 \mathrm{~V}$ & 1 & دكتور اه & $\wedge$ \\
\hline & & $1 \ldots$ & 10 & & المج \\
\hline
\end{tabular}

البحث التي تتص على عدم وجود علاقة ارتباط معنوية بين

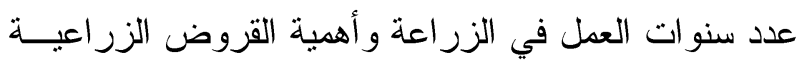

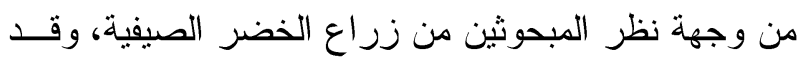

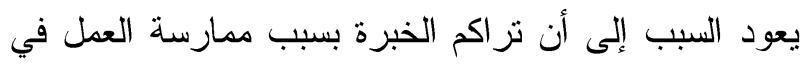

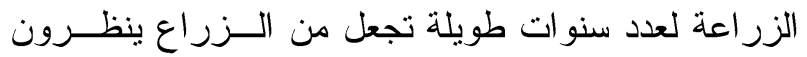
بحدق وتركيز لأهمية القروض الزر اعية، ومدى فائدتها في تبني التقانات الزر اعية الحديثة، بالإضافة إلى وجود الحاجة الفعلية لهذه القروض لاستخدامها في تبني التقانات الزر اعية

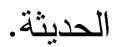

رابعاً: التعرف على مشكلات الحصـــول علـــى القــروض الزراعية من قبل زراع الخضر الصيفية.

أظهرت نتائج جدول(7) البحث بأن مشكلات الحصـــــ

على القروض الزر اعية من فبل زراع الخضــر الصــيفية

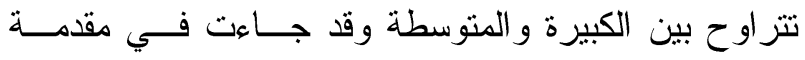
المشكلات الكبيرة مشكلة(صعوبة الحصول على القـروض الزر اعية بسبب الضو ابط المفروضة عليها) بمتوسط حسابي عابي

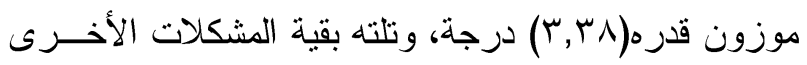
في حين جاءت مشكلة(فترات التسديد منقاربة مما يزيد من

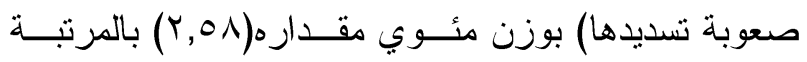

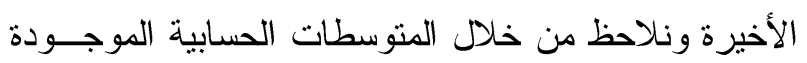
إن في الغالب جميعها تحد من استخدام القروض الزر اعية في تبني التقانات الزر اعية الحديثة وقد يكون السبب وجـــود

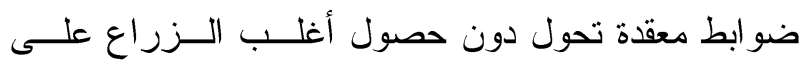
القروض الزر اعية وتدرجت بقية المشاكل الأخرى.
ولغرض معرفة فيما إذا كانت هنــاك علاقــة ارتبــاط معنوية بين التحصيل الدراسي وأهمية القروض الزراعيـة من وجهة نظر المبحوثين استخدم معامل الارتباط سبيرمان الذي كانت قيمته(99 ب, •) و هي قيمة معنوية عند المتــوى الاحتمالي( ( ., ))، وتشي هذه العلاقة الــى ان المتغيــرين يتحركان في نفس الاتجاه. r- عدد سنوات العمل في الزراعة: أظهرت نتائج البحث أن عدد المبحوثين الــذين لــديهر

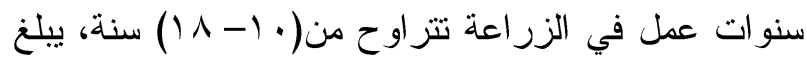

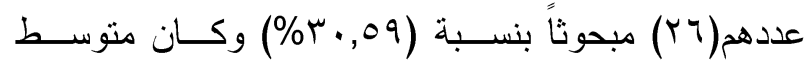

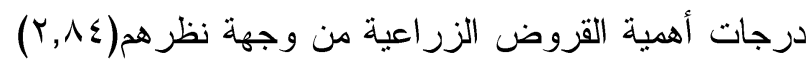

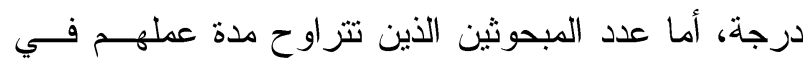

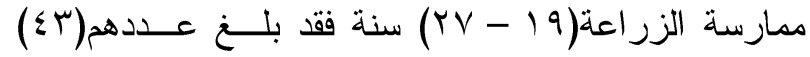

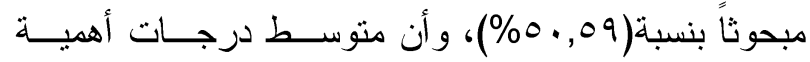

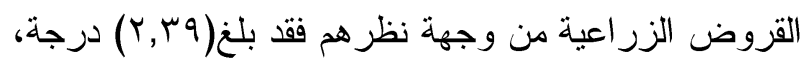
في حين كان عدد المبحوثين في الفئة الثالثة الذين تتــراوح مدد ممارستهم الزراعــة(r

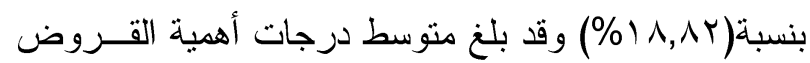

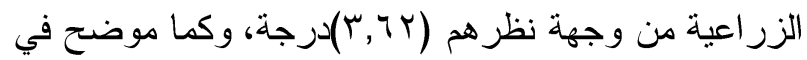

الجدول(0).

ولغرض تحديد العلاقة الإزتباطية بـين عـدد ســنوات العمل في الزر اعة و أهمية القـروض الزر اعيــة اســتخدم

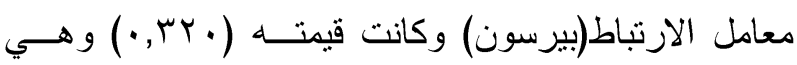
معنوية عند مستوى احتمال( ( , •))، وبذلك نرفض فرضية 
جدول ه. توزيع المبحوثين وفقاً لفئات درجاتعلهم الزراعي ومتوسط درجات أهمية كل فئة ومعامل الارتباط

\begin{tabular}{|c|c|c|c|c|c|}
\hline معامل ألارتباط بيرسون & متوسط درجات ألأهمية & $\%$ & 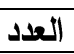 & الفئات (سنـه) & 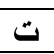 \\
\hline \multirow{4}{*}{ • } & $Y, \wedge \varepsilon$ & $r \cdot, 09$ & $r y$ & ( ) ( 1 ( ) قصيرة & 1 \\
\hline & $r, r q$ & $0 ., 09$ & $\varepsilon r$ & (YV - (Y) متوسطة & r \\
\hline & $r, 7 Y$ & $1 \wedge, \wedge Y$ & 17 & 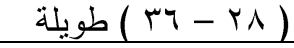 & $r$ \\
\hline & & $1 \ldots$ & 10 & & المج \\
\hline
\end{tabular}

جدول 7. مشكلات استخدام القروض الزراعية من وجهة نظر زراع الخضر الصيفية في قضاء الشرقاط.

\begin{tabular}{|c|c|c|c|c|c|c|c|c|c|c|c|}
\hline \multirow{3}{*}{ الرتبة } & \multirow{3}{*}{ المستوسي } & \multicolumn{8}{|c|}{ حجم المشكلات } & \multirow{3}{*}{ المشكلات المتعلقة بالقروض } & \multirow{3}{*}{ ث } \\
\hline & & \multicolumn{2}{|c|}{ غير موجودة } & \multicolumn{2}{|c|}{ قليلة } & \multicolumn{2}{|c|}{ متوسطة } & \multicolumn{2}{|c|}{ كبيرة } & & \\
\hline & & $\%$ & العدد & $\%$ & العدد & $\%$ & العدد & $\%$ & العدد & & \\
\hline 1 & r, rی & - & - & $\gamma, \cdot 0$ & 1 & $\leqslant V, .0$ & $\varepsilon$. & $\leqslant 0,9$. & rq & 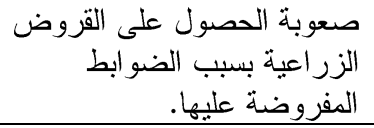 & 1 \\
\hline r & $r, r v$ & - & - & $1 V, T 4$ & 10 & $r V, .0$ & r & $00, Y_{9}$ & $\leqslant V$ & لمشتاريع أخرى غير زر القراعية. & r \\
\hline$r, 0$ & r,YA & r, ro & r & $10, r_{1}$ & Ir & $r \varepsilon, 11$ & $r q$ & $\varepsilon \wedge, r \mu$ & $\varepsilon$ & لتعليم والزر د تعليمات مديفة استخدوسامها. & $r$ \\
\hline$r, 0$ & $r, Y \wedge$ & $v, .0$ & 1 & $10, r_{9}$ & ir & r. & IV & OV,74 & $\leq 9$ & بعإِ القامة مشاريع زرض الزر اعية لاتكفي & $\varepsilon$ \\
\hline 0 & Y, १६ & 0,9 & 0 & Yr,OY & $r$. & $\{1,1 v$ & ro & $(9, \leqslant)$ & ro & 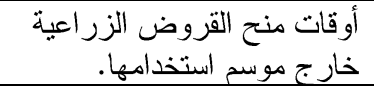 & 0 \\
\hline 7 & $Y, \wedge \wedge$ & 11,14 & 1. & $11, \sqrt{ } 4$ & 1. & Or,9T & «o & Yr,OY & $r \cdot$ & أكثر الزر الفائدة عن الى القروض عليهاء. & 9 \\
\hline v & $r, 0 \Lambda$ & $1 V, 74$ & 10 & $r 0, r_{q}$ & $r$. & $1 V, 74$ & 10 & $r q, \Sigma)$ & ro & فنر صعوبة التسديد منقاربة مما يزيد & V \\
\hline
\end{tabular}

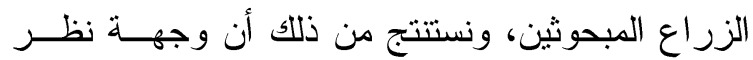

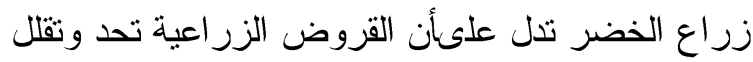
من تكاليف الإنتاج، كما أظهرت نتائج البحث أن عبارة

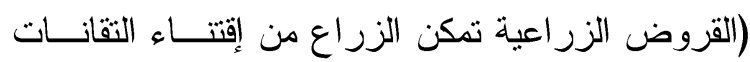
الزر اعية وتننيها مما ينعكس على سعادة ور احة نفســية اهـية

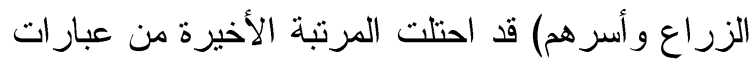
أهمية القروض الزر اعية، ونستتنج من ذللك إن أهميـــة هذه الفقرة اقل من بقية العبار ات التي سبقتها. r- أظهرت نتائج البحث وجود علاقة ارتباط معنوية بـين أهمية القروض الزر اعية من وجهة نظر زراع الخضر

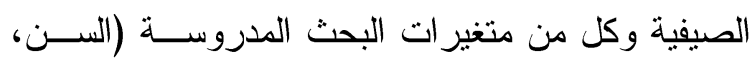
و التحصيل الدراسي، و عدد سنوات العمل في الزر اعة)، نستتتج من ذلك إن لكل من هــذه المتغيـرات علاقــة

\section{الاستنتاجات}

1 - أظهرت نتائج البحث أن غالبية المبحوثين يقعون ضمن الفئة عالية الأهمية وكان عددهم (

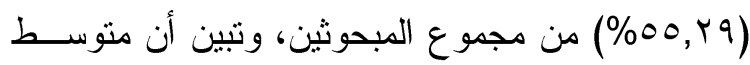

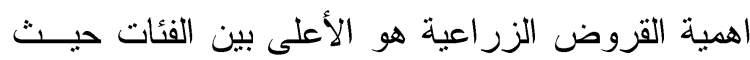
بلغ (r,00) درجة، ونستنتج من ذلك أن هناك أهميـــة عالية للقروض الزر اعية فــي مجــال تبنـــي التقانــات

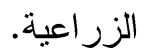

r- أظهرث نتائج البحث أن عبارة (القــروض الزراعيــة تسهم وبشكل و اضـح في تقليل التكاليف بالنسبة للــزر اع مما يزيد من صافي الربح) احتلت المرتبة الأولى مــن بـن

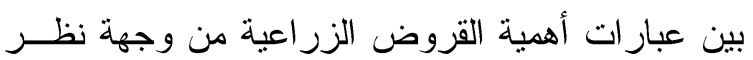




$$
\text { المـــــــــ }
$$

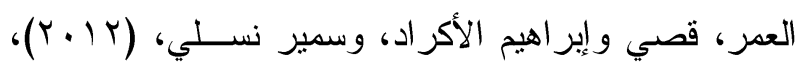

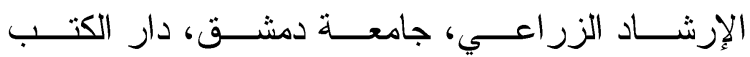

و المطبو عات الجامعية، دمشق، سوريا.

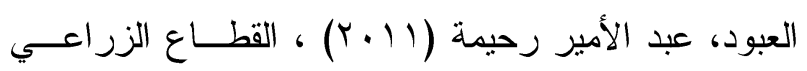
و اقعه ومشاكله و آفاق تتميته، عمان، الأردن.

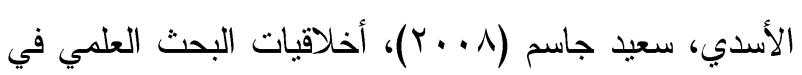

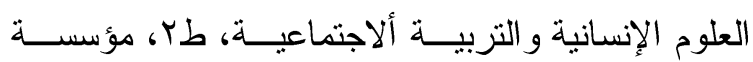
وارث النقافية قسم الدراسات و البحوث، العراق.

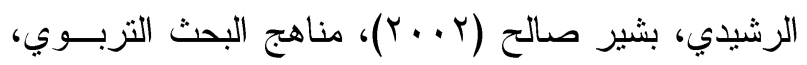
طا، دار الكتب الحديثة، كلية التربية، جامعة الكويت.

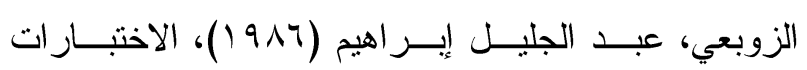

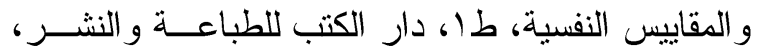

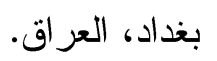

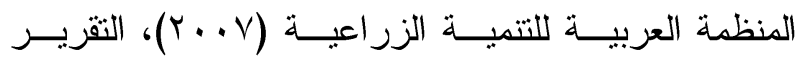

$$
\text { السنوي، جامعة الدول العربية. }
$$

المنظمة العربية للتتمية الزراعية (1997(1)، دراسة قوميــة

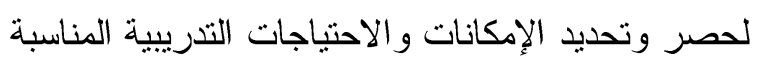

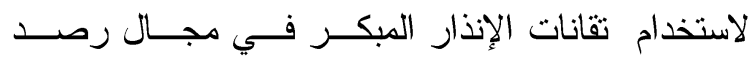

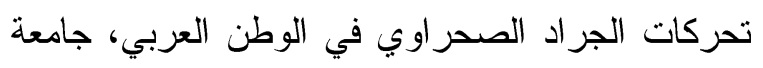
الدول العربية، الخرطوم، السودان.

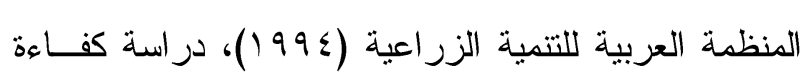

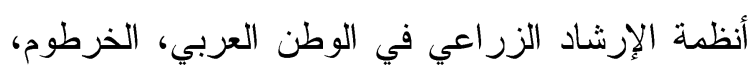

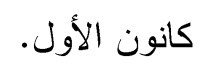

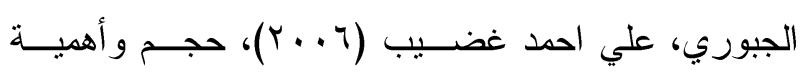
مشاكل نقل التقانات الزراعية من وجهة نظر الموظفين

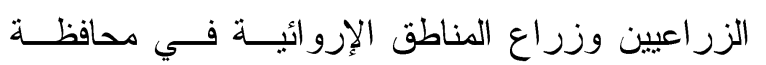

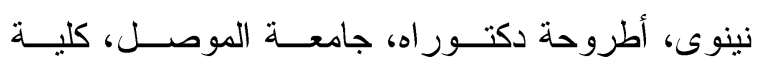
الزراعة و الغابات، قسم الإرشاد الزراعي، العراق.
ارتباطيه جعلت من المبحوثين يحددون أهمية القروض الزر اعية بشكل صحيح.

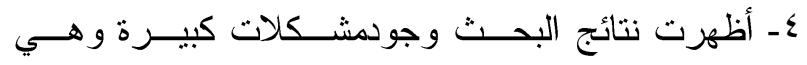

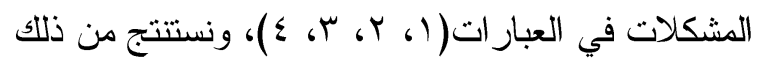

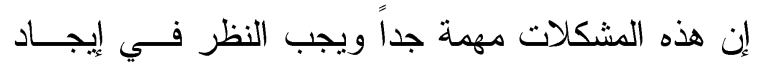
الحلول المناسبة لها.

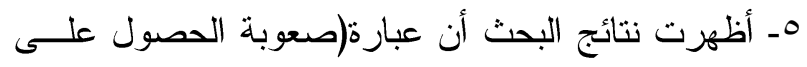
القروض الزراعية بسبب الضوابط المفروضة عليها) قد الدي

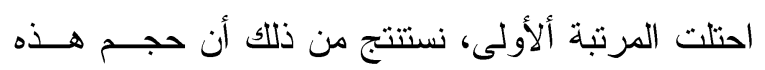
المشاكل أكثر حدة من المشاكل التي تلتها.

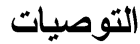

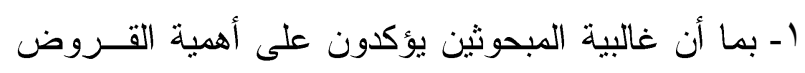

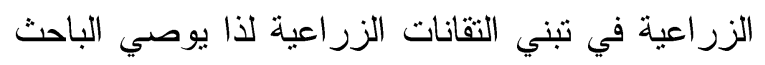

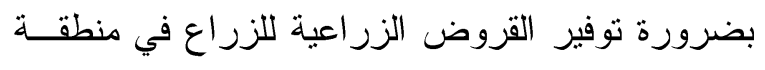

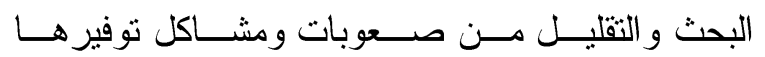
وتوزيعها.

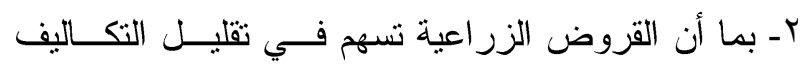

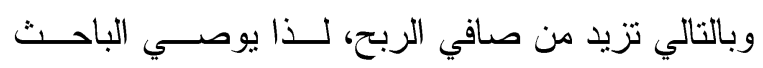

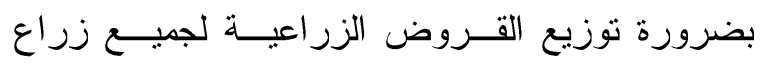

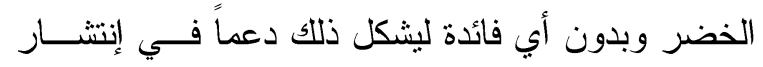
الثقانات الزر اعية الحديثة. r- يوصي الباحث بالنظر إلى مشكلات استخدام القـروض

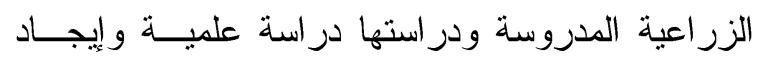
الحلول المناسبة لكل منها.

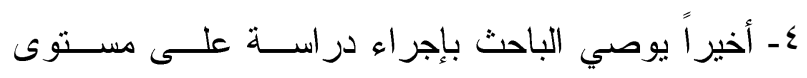

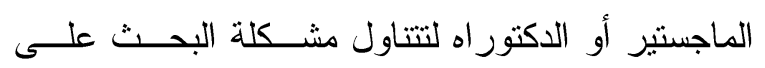

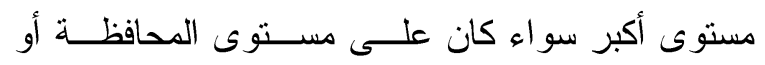

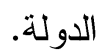




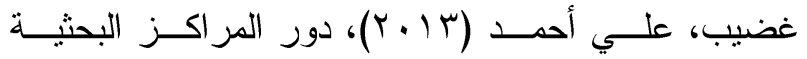

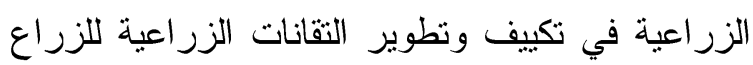
في محافظة نينوى و علاقته بــبعض العوامــلـ، مجلـــة

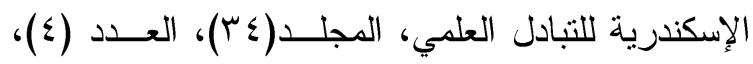
جمهورية مصر العربية. غضيب، علي أحمد (با • Y)، دور المرشدين الـزر اعيين في عملية نقل التقانات الزر اعية إلى الزراع في محافظة نينوى وعلاقته ببعض المتغيرات، مجلـــة الإســـكندرية

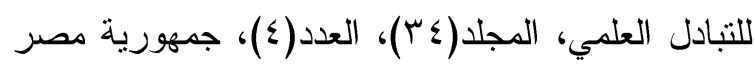

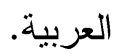

غضيب، علي أحمد، ومحمود حديس جاسم، وسمير حسين

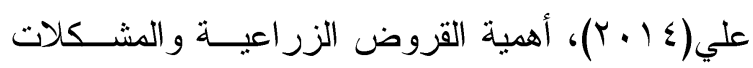

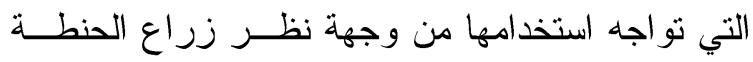
المروية في الساحل الأيمن من قضاء الشرقاط بمحافظة صلاح الدين، مجلة جامعة تكريت للعلــوم الزر اعيــة،

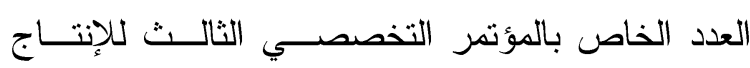
النباتي، كلية الزر اعة، جامعة تكريت، العراق. غضيب، علي أحمد، وماجد خليل علــي، ومحمــد عمـر

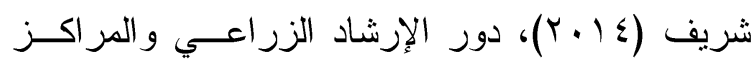

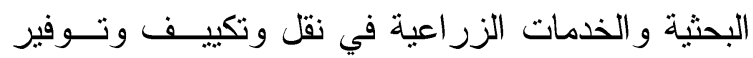

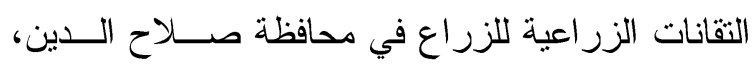

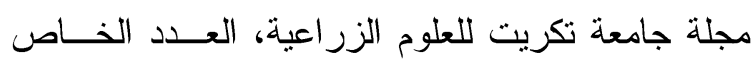

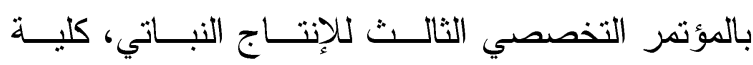
الزر اعة، جامعة تكريت، العر اق.
الطنوبي، محمد عمر (1 ( . ب)، تكييف التكنولوجيا الحديثة لمتطلبات التتمية في الدول النامية، طا، مكتبة ومطبعة الإشعاع الفنية، الإسكندرية. جامعة عين شمس، دار الضيافة، القاهرة(r . . ب)، المؤتمر العلمي الثالث عشر، مناهج التعليم و الثــورة المعرفيــة و التكنولوجية المعاصرة، مجلة مركز البحوث التربوية،

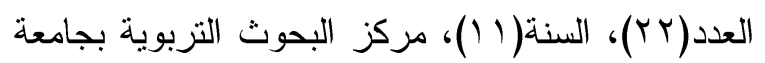

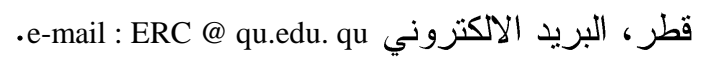
حسن، عبد الباسط محمد (99V ())، التتميــة الاجتماعيـة، القاهرة، مكتبة و وبنة.

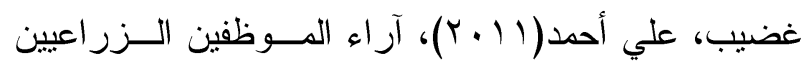

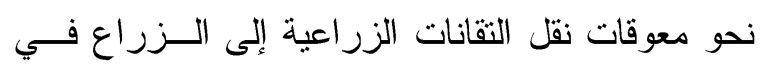

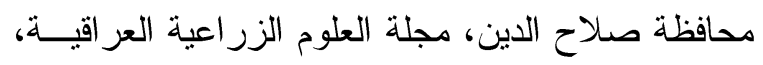
كلية الزر اعة، جامعة بغداد، المجلد (ب \&)، العدد (ب). غضيب، علي أحمد، وطلال سعيد(ب (Y)، تقويم الأنشطة ألإرشادية للموظفين الزر اعيين في مجال مكافحة الآفات الزر اعية في محافظة صلاح الدين، مجلة تكريت للعلوم الزر اعية، كلية الزراعة، جامعة تكريت، المجلد (س ())،

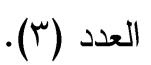

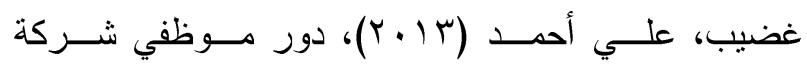

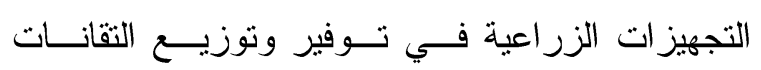

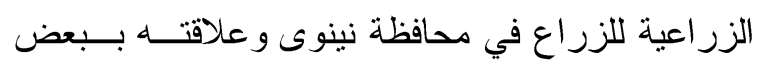

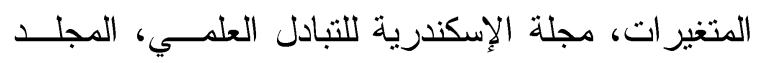
(ع r)، العدد (ع)، جمهورية مصر العربية. 
مجلة الإسكندرية للتبادل العلمى - (مجلدهب العدد ) أكتوبر - ديسمبر ع ا ب r

\title{
ABSTRACT \\ The Importance of Agricultural Loans in Adopting The Modern Agricultural Techniques from The Perspective of The Farmers of Summer Vegetables in Al-Shirqat, Salah El-Deen and Their Relation with Some Variables
}

\author{
Ali Ahmed Ghaidhaib
}

This research aims at knowing the importance of agricultural loans in adopting the agricultural techniques from the perspective of the farmer in Al-Shirqat and detecting its importance as well as finding the correlation between the importance of the agricultural loans and all of the variables like age, literacy and the number of work years in farming. As well as knowing the limits of using these loans and determining the size of these limits. This study includes all the summer vegetable farmers in Al-Shirqat, the right-hand side, who are registered in the Agriculture Branch (200) farmers. After removing the exploration sample (30), a random simple sample has been taken from them $(50 \%)$ after that the number of the researched farmers in the study sample (85). The data of the study has been collected by a questionnaire form done especially for knowing the importance of these loans. The first part includes data concerning the farmers, whereas the second part includes a scale for the importance of these loans consisted of (10) experimental paragraphs and the third part consisted of a scale for knowing the limits of using these loans from their perspective. The visible and the content prove has been assured. Steadiness has been accounted by half partition way and the modulus was $(0,809)$. After classifying data, a number of statistic means has been used of great importance are (Berson' simple correlation modulus, rank correlation modulus, the standard deviance, the arithmetic average, the scaled arithmetic average). The results showed that the greater ratio of the researched was under great importance and they were (47) of percentage (\%55.29) of the researched ratio. They also indicated that the statement (the agricultural loan clearly contributes in reducing the costs of the farmer which increases the profit) takes the lead of a percentage (\%87.85). They as well indicated that there is an abstract correlation with the studied variables. They finally indicated that the limit shown in the first rank in accordance with size is (the difficulty in getting the loans because of the regulations) and in scaled average (3.38), whereas the limit (the periods of payment are very close which make them difficult) has come in the last rank. Depending on these results, some conclusions have been drawn, some recommendation has been given and some suggestions have been made. 